
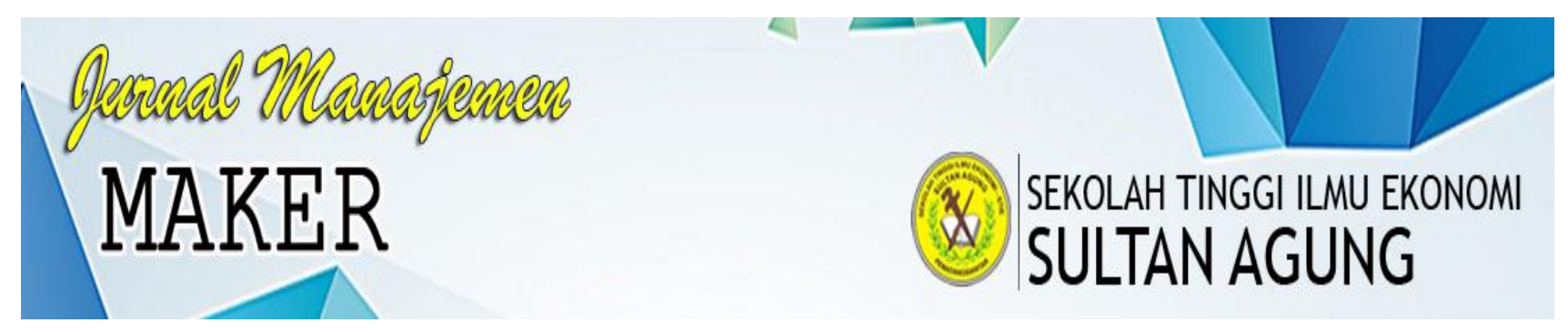

\title{
PENGARUH REKRUTMEN DAN PENEMPATAN TERHADAP KINERJA PEGAWAI \\ PADA KANTOR PELAYANAN PERBENDAHARAAN \\ NEGARA (KPPN) PEMATANGSIANTAR
}

Oleh:

Nurul Safika Agus

S1 Manajemen

Darwin Lie, Efendy, Julyanthry

\begin{abstract}
Abstrak
Penelitian ini bertujuan untuk menguji pengaruh rekrutmen dan penempatan terhadap kinerja pegawai baik secara parsial maupun simultan. Populasi penelitian ialah pegawai tetap Kantor Pelayanan Perbendaharaan Negara (KPPN) Pematangsiantar sebanyak 23 pegawai. Data dalam penelitian ini adalah data primer dan data sekunder. Data dilakukan dengan menggunakan kuesioner, wawancara dan dokumentasi. Metode Analisis yang digunakan ialah Analisis Kualitatif dan Analisis Kuantitatif. Analisis Kuantitatif menggunakan aplikasi SPSS Versi 21. Hasil penelitian dan uji hipotesis menunjukkan bahwa variabel rekrutmen dan penempatan berpengaruh signifikan terhadap kinerja pegawai baik secara simultan dan parsial.
\end{abstract}

Kata Kunci: Rekrutmen, Penempatan, dan Kinerja Pegawai

\section{Abstract}

The objective of this research was to test the influence of recruitment and placement to employee performance in a simultaneous and partial. The population used in this research are 23 employee. Research data were primary data and secondary data. Data were throught questionnaires, interviews, and documentaries. Analyzing method used was Qualitative Analysis and Analysis Quantitative. Quantitative Analysis proceed with application of SPSS version 21. The finding of this research and hypotesis test showed that recruitment and placement had significant influence to the employee performance partially and simultaneously.

Keywords: Rekruitmen, Placement, and Employee Performance

\section{A. PENDAHULUAN}

\section{Latar Belakang Masalah}

Kinerja pegawai di dalam setiap perusahaan merupakan salah satu faktor penting dalam sebuah organisasi atau perusahaan guna mencapai tujuan dan sasarannya melalui usaha kooperatif sekelompok orang di dalamnya, sehingga dapat dikatakan kinerja adalah salah satu faktor penentu berhasil atau tidak suatu perusahaan dalam mencapai tujuannya.

$$
\text { Pada kantor Pelayanan }
$$

Perbendaharaan Negara (KPPN)

Pematangsiantar diukur dari Peraturan Pemerintah Republik Indonesia Nomor 46 Tahun 2011Tentang Penilaian Prestasi Kerja Pegawai Negeri Sipil. Penilaian prestasi kinerja pegawai negeri sipil menggabungkan antara penilaian sasaran kinerja pegawai dengan penilaian perilaku kerja. Sasaran kerja pegawai yang meliputi kuantitas, kualitas, waktu dan biaya. Perilaku kerja yang meliputi orientasi pelayanan, integritas, komitmen, disiplin, kerja sama, dan kepemimpinan. Dimana dari dimensi sasaran kerja disebabkan belum semuanya pegawai memiliki pengetahuan yang luas untuk digunakan dalam pekerjaannya dibidang masingmasing pegawai. Ketidakoptimalan lainnya pada indikator ketepatan dalam menyelesaikan tugas yang dimana setiap pegawai masih ada yang tidak tepat waktu dalam menyelesaikan pekerjaannya. Pada 
dimensi perilaku kerja di indikator tingkat kehadiran seringkali pegawai datang terlambat saat adanya kegiatan sharing session yang dilaksanakan setiap hari Senin dan Rabu pagi. Dari indikator kerja sama dimana masih ada pegawai yang lebih mementingkan tugas pribadi dibandingkan bekerja sama menyelesaikan pekerjaan yang diberikan secara tim.

Menurut Nurjaman (2014:68), proses untuk memperoleh calon pegawai sebanyak-banyaknya untuk diseleksi potensinya sehingga yang diterima sebagai pegawai merupakan pelamar yang paling berkualitas dan kompeten yang dapat meningkatkan kinerja pegawai pada perusahaan. Dalam Peraturan Pemerintah Republik Indonesia Nomor 78 Tahun 2013 Tentang Perubahan Kedua Atas Peraturan Pemerintah dimensi rekrutmen mencakup kompetitif, adil, objektif, transparan, bersih dari praktik korupsi, dan tidak dipungut biaya. Dimana rekrutmen yang dilakukan telah sesuai dengan peraturan perundangan yang ditetapkan, akan tetapi fenomena rekrutmen terdapat pada dimensi kompetitif yang dapat diposisikan sebagai suatu kondisi perebutan atau keadaan berkompetisi. Tetapi masih kurangnya daya saing yang diciptakan oleh pegawai, sehingga tidak adanya peningkatan prestasi dalam bekerja. Dari dimensi transparan yaitu pegawai selalu mencari pengetahuan, kejelasan, dan kepercayaan dari yang memperkerjakan mereka. Tetapi sebagian pegawai belum mendapatkan kepuasan bekerja ketika kepercayaan diberikan kepadanya.

Dan menurut Suwatno (2003:133), penempatan merupakan proses menempatkan orang yang tepat dan jabatan yang sesuai dengan minat dan kemampuannya sehingga sumber daya manusia yang ada menjadi produktif dan dapat meningkatkan kinerja pegawai. Dalam Peraturan Pemerintah Republik Indonesia Nomor 13 Tahun 2002, dimensi penempatan mencakup faktor pengalaman, faktor usia, faktor pendidikan, faktor kesehatan fisik dan mental, faktor kompetensi. Fenomena penempatan terdapat pada dimensi pendidikan yang mana pegawai merasa kesulitan dalam menangani pekerjaan yang tidak sesuai dengan latar belakang pendidikannya. Dari dimensi kompetensiyaitu masih adanya pegawai yang kesulitan dalam penggunaan teknologi seperti komputer dalam menyelesaikan suatu pekerjaan.

\section{Rumusan Masalah}

a. Bagaimana gambaran rekrutmen, penempatan dan kinerja pegawai padaKantor Pelayanan Perbendaharaan Negara (KPPN)Pematangsiantar.

b. Bagaimana pengaruh rekrutmen dan penempatan terhadap kinerja pegawai pada Kantor Pelayanan Perbendaharaan Negara (KPPN) Pematangsiantar secara simultan dan parsial.

\section{Tujuan Penelitian}

a. Untuk mengetahui gambaran rekrutmen, penempatan dan kinerja pegawai pada Kantor Pelayanan Perbendaharaan Negara (KPPN) Pematangsiantar.

b. Untuk mengetahui pengaruh rekrutmen dan penempatan terhadap kinerja pegawai pada Kantor Pelayanan Perbendaharaan Negara (KPPN) Pematangsiantar secara simultan dan parsial.

\section{Metode Penelitian}

Adapun desain penelitian yang digunakan dalam penulisan penelitian ini adalah penelitian kepustakaan (Library Research), Penelitian lapangan (Field Research).Tehnik pengumpulan data yang dipergunakan dalam penelitian ini adalah metode wawancara, metode kuisioner, metode dokumentasi.

\section{B. LANDASAN TEORI}

\section{Manajemen}

Manajemen dikatakan baik apabila mampu mengatur orang-orang di dalam perusahaan untuk dapat bekerja secara lebih baik sehingga tujuan perusahaan dapat tercapai. Menurut Handoko (2003:8), "manajemen adalah proses perencanaan, pengorganisasian, pengarahan, dan pengawasan usaha-usaha oleh organisasi dan penggunaan sumber daya-sumber daya organisasi lainnya agar mencapai tujuan organisasi yang telah ditetapkan”.

Menurut Robbins dan Mary (2010:7), "manajemen merupakan proses melibatkan 
aktivitas-aktivitas koordinasi dan pengawasan terhadap pekerjaan orang lain, sehingga pekerjaan tersebut dapat diselesaikan secara efisien dan efektif'. Sedangkan menurut Daft (2002:8), "manajemen adalah pencapaian tujuan organisasi dengan cara yang efektif dan efisien melalui perencanaan, pengorganisasian, kepemimpinan, dan pengendalian sumber daya organisasi".

Manajemen sangat dibutuhkan dalam sebuah organisasi, karena pengadaan manajemen yang baik akan menghasilkan sebuah pekerjaan yang baik pula. Berdasarkan uraian di atas maka dapat disimpulkan manajemen adalah suatu proses perencanaan, pengorganisasian, pengambilan keputusan, pengendalian dan pengarahan untuk mencapai tujuan organisasi secara efektif.

\section{Manajemen Sumber Daya Manusia}

Dalam suatu organisasi, manajemen sumber daya manusia memiliki peranan penting. Perlu diingat bahwa sumber daya manusia sendiri sebagai faktor produksi yang memberikan masukan (input) yang diolah organisasi, sehingga menghasilkan pengeluaran (output). Tanpa adanya sumber daya manusia, operasional organisasi tidak dapat berjalan dengan lancar. Menurut Fahmi (2016:1), "manajemen sumber daya manusia didefinisikan sebagai rangkaian kegiatan organisasi yang diarahkan untuk menarik, mengembangkan, dan mempertahankan tenaga kerja yang efektif'. Sedangkan menurut Mondy (2008:4), "manajemen sumber daya manusia adalah pemanfaatan sejumlah individu untuk mencapai tujuan-tujuan suatu organisasi”.

Kemudian menurut Bangun (2012:5), "manajemen sumber daya manusia adalah suatu proses perencanaan, pengorganisasian, penyusunan staf, penggerakan, dan pengawasan terhadap pengadaan, pengembangan, pemberian kompensasi, pengintegrasian, pemeliharaan, dan pemisahan tenaga kerja untuk mencapai tujuan organisasi”".

Manajemen sumber daya manusia merupakan aspek yang penting dalam kehidupan, karena dalam pengadaannya manajemen sumber daya manusia dapat menentukan keberhasilan suatu organisasi tersebut.Berdasarkan uraian tersebut maka penulis dapat menyimpulkan bahwa manajemen sumber daya manusia merupakan pendayagunaan sumber daya manusia yang dilakukan melalui pengembangan sumber daya manusia, pemanfaatan sumber daya manusia dan pengelolaan sumber daya manusia secara efektif dan efisien.

\section{Rekrutmen}

Rekrutmen ialah salah satu fungsi manajemen sumber dayamanusia untuk mendapatkan calon pegawai yang kemudian diseleksi untuk mendapatkan yang terbaik sesuai dengan persyaratan yang dibutuhkan melalui proses rekrutmen. Menurut Zainal, dkk (2015:118), "rekrutmen didefinisikan sebagai proses menentukan dan menarik pelamar yang mampu untuk bekerja dalam suatu organisasi, proses ini dimulai ketika para pelamar dicari dan berakhir ketika lamaran-lamaran mereka diserahkan atau dikumpulkan". Sedangkan menurut Mathis dan John (2006:227), "rekrutmen adalah proses menghasilkan satu kelompok pelamar yang memenuhi syarat untuk pekerjaan-pekerjaan organisasional". Kemudian menurut Gomes (2003:105) "rekrutmen merupakan proses mencari, menemukan, dan menarik para pelamar untuk dipekerjakan dalam dan oleh suatu organisasi".

Rekrutmen salah satu proses seleksi guna mendapatkan kualitas sumber daya manusia unggul yang dapat mencapai tujuan dan sasaran organisasi. Dari uraian di atas penulis dapat menyimpulkan bahwa rekrutmen merupakan proses mencari, menemukan dan menarik para pelamar untuk dipekerjakan dalam suatu organisasi.

\section{Penempatan}

Nurjaman (2014:152), "penempatan (placement) merupakan penugasan (assignment) atau penugasan kembali (reassignment) seorang pegawai pada sebuah jabatan baru yang sebagian besar keputusan penempatan diambil oleh manajer lini, yaitu atasan langsung karyawan yang bersangkutan". Menurut Mathis dan John (2006:262), "penempatan 
didefinisikan sebagai menempatkan posisi seseorang ke posisi pekerjaan yang tepat, seberapa baik seorang pegawai cocok dengan pekerjaanya akan mempengaruhi jumlah dan kualitas pekerjaan". Sedangkan menurut Bangun (2012:159), "penempatan adalah proses penempatan pegawai sesuai dengan pengetahuan, keterampilan, dan kemampuan dengan persyaratan pekerjaan". Penempatan ialah serangkaian kegiatan yang dimulai ketika perusahaan memerlukan tenaga kerja dan membuka lowongan sampai mendapatkan calon pegawai yang diinginkan. Maka penulis menyimpulkan bahwa penempatan kerja merupakan upaya menempatkan posisi seorang pegawai pada sebuah jabatan baru yang sesuai dengan pengetahuan, keterampilan dan kemampuan yang dimilikinya.

\section{Kinerja Pegawai}

Menurut Mangkunegara (2005:9), "kinerja adalah hasil kerja secara kualitas dan kuantitas yang dicapai oleh seorang karyawan dalam melaksanakan tugasnya sesuai dengan tanggung jawab yang diberikan kepadanya". Rivai (2004:309), "kinerja adalah perilaku yang nyata dan ditampilkan setiap orang sebagai kualitas kerja yang dihasilkan oleh karyawan sesuai dengan perannya dalam perusahaan”. Sedangkan menurut Mathis dan John (2006:113), "kinerja adalah suatu hasil kerja yang dicapai seseorang dalam melaksanakan tugas-tugas yang dibebankan kepadanya yang disarankan atas pengalaman, kesungguhan, kecakapan serta waktu".

Kinerja pegawai sangat berguna dalam melaksanakan pekerjaannya sesuai dengan syarat-syarat yang telah ditentukan. Berdasarkan uraian tersebut penulis dapat menyimpulkan bahwa, kinerja adalah tingkat pencapaian hasil kerja secara kualitas dan kuantitas yang dicapai oleh seorang pegawai dalam waktu tertentu demi memenuhi tugas dan tanggung jawab yang telah diberikan kepadanya.

Presiden Republik Indonesia telah menetapkan peraturan mengenai Sasaran Kerja Pegawai, yaitu Peraturan Pemerintah Republik Indonesia Nomor 46 Tahun 2011
Tentang Penilaian Prestasi Kerja Pegawai Negeri Sipil. Penilaian prestasi kerja pegawai negeri sipil merupakan suatu proses penilaian secara sistematis yang dilakukan oleh pejabat penilai terhadap sasaran kerja pegawai dan perilaku kerja pegawai negeri sipil (pasal 1 ayat 2 PP No. 46 Tahun 2011). Tujuannya adalah untuk mengevaluasi kinerja pegawai negeri sipil, yang dapat memberi petunjuk bagi manajemen mengevaluasi kinerja unit dan kinerja organisasi secara keseluruhan. Penilaian prestasi kinerja Pegawai Negeri Sipil menggabungkan antara penilaian sasaran kinerja Pegawai Negeri Sipil dengan penilaian perilaku kerja. Penilaian prestasi kerja tersebut terdiri dari dua unsur yaitu sasaran kinerja pegawai dan perilaku kerja dengan bobot penilaian masingmasing unsur sasaran kinerja pegawai sebesar $60 \%$ dan perilaku kerja sebesar $40 \%$. Hasil penilaian prestasi kerja pegawai negeri sipil dimanfaatkan sebagai dasar pertimbangan pemerintah.

\section{PEMBAHASAN}

\section{Analisis}

\section{a. Deskriptif Kualitatif}

Analisis deskriptif dimaksudkan untuk mendapatkan gambaran atau deskripsi mengenai tanggapan dari pegawai mengenai pengaruh penempatan dan rekrutmen terhadap kinerja pegawai pada Kantor Pelayanan Perbendaharaan Negara (KPPN) Pematangsiantar.Sesudah pengujian data maka langkah selanjutnya peneliti melakukan pengkajian analisis kualitatif sebagai gambaran fenomena dari variabel penelitian pada saat sekarang ini.

Interval kelas $=\frac{\text { Nilai Tertinggi }- \text { Nilai Terendah }}{\text { (jumlah kelas interval) }}$

$=\frac{5-1}{5}$

$=\frac{4}{5}$
$=0,8$

Dari rumus di atas, diperoleh nilai interval kelas $=0,8$, sehingga berlaku ketentuan kategori dengan hasil sebagai berikut: 
Tabel 1

Nilai Interval dan Kategori Jawaban Responden

\begin{tabular}{|c|c|}
\hline Nilai Interval & Kategori \\
\hline $1,00-1,80$ & Sangat Tidak Baik \\
\hline $1,81-2,60$ & Tidak Baik \\
\hline $261-3,40$ & Cukup Baik \\
\hline $3,41-4,20$ & Baik \\
\hline $4,21-5,00$ & Sangat Baik \\
\hline
\end{tabular}

Sumber: hasil pengolahan data (2018)

1) Gambaran Rekrutmen Pada Kantor Pelayanan Perbendaharaan Negara (KPPN) Pematangsiantar

Pada dimensi kompetitif pada indikator daya saing berada pada rata-rata 3,65 dengan kriteria jawaban baik, dikarenakan setiap pegawai sudah selalu berkompetisi untuk mencapai posisi yang mereka inginkan. Indikator kemampuan di tempat kerja berada pada rata-rata 3,48 dengan kriteria jawaban baik, hal ini dikarenakan pegawai memiliki kemampuan untuk melaksanakan setiap tugasnya seperti kemampuan bersaing dalam menyelesaikan pekerjaan namun ada beberapa pegawai yang kurang dalam bersaing sehingga tidak adanya peningkatan prestasi dalam bekerja. Indikator keahlian yang dimiliki berada pada rata-rata 3,65 dengan kriteria jawaban baik, hal ini dikarenakan setiap pegawai memiliki keahlian yang berbeda-beda untuk meningkatkan prestasi kerja.

Pada dimensi adil pada indikator tingkat keadilan di tempat kerja berada pada rata-rata 3,65 dengan kriteria jawaban baik, dikarenakan setiap pegawai mendapatkan perlakuan yang adil merata tanpa adanya pilih kasih dalam pekerjaannya. Kemudian indikator kesetaraan antar pegawai di tempat kerja berada pada rata-rata 3,74 dengan kriteria jawaban baik, hal ini disebabkan karena pegawai selama bekerja merasa nyaman dan tidak dibandingbandingkan dengan pegawai lainnya. Dari indikator perlakuan yang diterima selama bekerja berada pada rata-rata 3,65 dengan kriteria jawaban baik, hal ini dikarenakan setiap pegawai mendapatkan perlakuan yang sama antar pegawai.

Selanjutnya untuk dimensi objektif pada indikator proses pendaftaran yang diadakan pihak instansi memperoleh nilai rata-rata 3,65 dengan kriteria jawaban baik, dikarenakan pemerintah telah transparan dalam proses pendaftaran melalui jalur online. Indikator proses rekrutmen yang dilakukan pihak instansi memperoleh nilai rata-rata 3,74 dengan kriteria jawaban baik, dikarenakan perekrutan yang dilakukan oleh instansi telah sesuai dengan peraturan pemerintah yang telah ditetapkan. Indikator penentuan kelulusan yang digunakan pihak instansi memperoleh nilai rata-rata 3,74 dengan kriteria jawaban baik, hal ini dikarenakan setiap penentuan kelulusan dilakukan secara terbuka oleh pihak instansi.

Kemudian pada dimensi transparan pada indikator keterbukaan pemerintah di tempat kerja memperoleh nilai rata-rata 3,52 dengan kriteria jawaban baik, dikarenakan setiap pelaksanaan tugas dilakukan secara terbuka oleh pemerintah tetapi masih adanya pegawai yang tidak mengetahui tentang keterbukaan ini dikarenakan kurangnya informasi. Indikator tingkat kebebasan yang dimiliki setiap orang selama bekerja berada pada rata-rata 3,48 dengan kriteria jawaban baik, hal ini dikarenakan, setiap pegawai diberi kebebasan seperti kepercayaan untuk menyelesaikan pekerjaan, tetapi sebagian pegawai belum mendapatkan kepuasan bekerja ketika kepercayaan diberikan kepada mereka.

Terakhir indikator upaya pengawasan memperoleh nilai rata-rata 3,65 dengan kriteria jawaban baik, hal ini dikarenakan pengawasan dilakukan kepada pegawai agar tidak ada yang lalai dalam bekerja. Lalu pada dimensi bersih dari praktik korupsi, pada indikator cara pembinaan oleh instansi memperoleh nilai rata-rata 3,65 dengan kriteria jawaban baik, dikarenakan instansi mengadakan sosialisasi yang bertujuan untuk meningkatkan kesadaran pegawai dalam praktik korupsi. Indikator pengendalian yang diberikan instansi memperoleh nilai rata-rata 3,48 dengan kriteria jawaban baik, dikarenakan instansi selalu melakukan pengendalian dalam mencegah adanya praktik korupsi. Indikator upaya pencegahan praktik korupsi memperoleh nilai rata-rata 3,65 dengan 
kriteria jawaban baik, dikarenakan instansi berupaya semaksimal mungkin untuk menghindari adanya korupsi.

Kemudian pada dimensi tidak dipungut biaya pada indikator biaya yang dibebankan kepada pelamar selama proses rekrutmen memperoleh nilai rata-rata 3,65 dengan kriteria jawaban baik, hal ini dikarenakan instansi tidak memungut biaya apapun dari pelamar karena proses rekrutmen ini dilakukan secara online. Indikator transparansi biaya rekrutmen calon pegawai negeri sipil memperoleh nilai rata-rata 3,65 dengan kriteria jawaban baik, hal ini dikarenakan instansi transparan bahwa tidak adanya biaya yang dibebankan oleh calon pegawai. Terakhir indikator kejujuran pegawai dalam administrasi penerimaan calon pegawai negeri sipil berada pada rata-rata 3,65 dengan kriteria jawaban baik, hal ini dikarenakan pegawai dituntut untuk selalu jujur mengenai administrasi calon pegawai.

Dari total jawaban responden mengenai kompetitif, adil, objektif, transparan, bersih dari praktik korupsi dan tidak dipungut biaya mendapat nilai ratarata sebesar 3,63 dengan kriteria jawaban baik. Kemudian nilai rata-rata tertinggi 3,74 dengan kriteria jawaban baik untuk untuk dimensi adil pada indikator kesetaraan antar pegawai dan dimensi objektif pada indikator proses rekrutmen yang dilakukan instansi dan penentuan kelulusan yang digunakan instansi.Sedangkan nilai rata-rata terendah sebesar 3,48 dengan kriteria jawaban baik untuk dimensi kompetitif pada indikator kemampuan, lalu dimensi transparan pada indikator kebebasan setiap orang dan terakhir dimensi bersih dari praktik korupsi pada indikator pengendalian yag diberikan pihak instansi.

\section{2) Gambaran Penempatan Pada Kantor Pelayanan Perbendaharaan Negara (KPPN) Pematangsiantar}

Untuk dimensi faktor pengalaman pada indikator pengalaman masa kerja berada pada rata-rata 3,48 dengan kriteria jawaban baik, hal ini dikarenakan pegawai dituntut memiliki masa kerja yang lama sehingga dapat meningkatkan kinerja. Indikator keterampilan selama masa kerja berada pada rata-rata 3,48 dengan kriteria jawaban baik, hal ini dikarenakan setiap pegawai memiliki keterampilan yang dibutuhkan. Indikator keahlian selama masa kerja berada pada rata-rata 3,52 dengan kriteria jawaban baik, dikarenakan pegawai dituntut memiliki keahlian sehingga dapat meningkatkan kinerjanya.

Lalu pada dimensi faktor usia di Indikator penyesuaian usia dengan jabatan memperoleh nilai rata-rata 3,61 dengan kriteria jawaban baik, dikarenakan penempatan pegawai telah sesuai dengan usia masing-masing pegawai sehingga pekerjaan tersebut dapat maksimal. Indikator penyesuaian usia dengan pekerjaan memperoleh nilai rata-rata 3,48 dengan kriteria jawaban baik, dikarenakan pegawai dengan usia lebih muda diberi pekerjaan yang menggunakan teknologi canggih dan yang lebih senior diberi pekerjaan yang tidak menuntut penggunaan teknologi canggih. Terakhir pada indikator produktivitas pegawai usia tua dalam bekerja berada pada rata-rata 3,65 dengan kriteria jawaban baik, dikarenakan pegawai yang lebih senior tetap produktivitas dalam mengerjakan pekerjaan mereka.

Dimensi faktor pendidikan dengan indikator penyesuaian pendidikan dengan beban kerja memperoleh nilai rata-rata 3,43 dengan kriteria jawaban baik, dikarenakan pegawai merasa pendidikan dengan beban kerja yang diberikan telah sesuai, tetapi ada pegawai yang mengalami kesulitan terhadap pekerjaan baru yang diberikan padanya. Indikator penyesuaian pendidikan dengan penempatan memperoleh nilai rata-rata 3,48 dengan kriteria jawaban baik, dikarenakan penyesuaian pendidikan para pegawai harus sesuai penempatan yang ada untuk meningkatkan kinerja dengan baik. Indikator pendidikan membantu dalam menyelesaikan tugas memperoleh nilai ratarata 3,48 dengan kriteria jawaban baik, dikarenakan pendidikan dan ilmu yang dimiliki pegawai membantu menyelesaikan tuntutan pekerjaan dalam pemecahan masalah.

Selanjutnya dimensi faktor kesehatan fisik dan mental pada indikator kondisi fisik selama masa kerja memperoleh nilai rata- 
rata 3,43 dengan kriteria jawaban baik, dikarenakan pegawai berusia di atas 50 tahun rentan terhadap berbagai gangguan penyakit. Indikator kondisi mental selama masa kerja memperoleh nilai rata-rata 3,52 dengan kriteria jawaban baik kemampuan mental pegawai harus ditingkatkan sehingga pegawai siap ditempatkan pada posisi strategis. Pada indikator kondisi dalam meningkatkan kinerja berada pada rata-rata 3,48 dengan kriteria jawaban baik, hal ini dikarenakan para pegawai dengan kondisi yang baik dapat meningkatkan kinerjanya.

Dimensi yang terakhir faktor kompetensi dengan indikator tingkat pengetahuan memperoleh nilai rata-rata 2,91 dengan kriteria jawaban cukup baik, dikarenakan masih ada beberapa pegawai yang kesulitan dalam menggunakan teknologi seperti komputer dan internet. Indikator tingkat keterampilan memperoleh nilai rata-rata 3,65 dengan kriteria jawaban baik, dimana setiap pegawai memiliki kreativitas dan keterampilan berdasarkan pengalaman kerja. Terakhir Indikator sikap selama masa kerja memperoleh nilai ratarata 3,48 dengan kriteria jawaban baik, dimana setiap pegawai mampu menjaga sikap antara atasan dengan bawahan yang baik dan menjadikan situasi keakraban dalam instansi.

Dari total jawaban responden mengenai penempatan berdasarkan faktor pengalaman, faktor usia, faktor pendidikan, faktor kesehatan fisik dan mental, dan faktor kompetensi mendapat nilai rata-rata sebesar 3,47 dengan kriteria jawaban baik. Kemudian nilai rata-rata tertinggi 3,65 dengan kriteria jawaban baik untuk dimensi faktor usia pada indikator produktivitas pegawai berusia tua dalam bekerja dan pada dimensi kompetensi pada indikator tingkat keterampilan. Sedangkan nilai rata-rata terendah sebesar 2,91 dengan kriteria jawaban cukup baik untuk dimensi faktor kompetensi pada indikator tingkat pengetahuan.

\section{3) Gambaran Kinerja Pegawai Pada Kantor Pelayanan Perbendaharaan Negara (KPPN) Pematangsiantar}

Dimensi sasaran kerja pegawai untuk indikator pencapaian target kerja memperoleh nilai rata-rata 3,48 dengan kriteria jawaban baik, dikarenakan pegawai antusias untuk mencapai target kerja yang baik sehingga pekerjaan berlebih tidak mempengaruhi sikap pegawai dalam bekerja. Indikator tanggung jawab hasil kerja memperoleh nilai rata-rata 3,48 dengan kriteria jawaban baik, dikarenakan pegawai dapat mempertanggungjawabkan hasil kerja yang dicapainya. Indikator kualitas hasil kerja memperoleh nilai ratarata 3,61 dengan kriteria jawaban baik, hal ini dikarenakan pegawai mampu menjaga hasil kerjanya dan dapat menyelesaikan pekerjaan dengan baik. Pada indikator ketelitian pegawai memperoleh nilai ratarata 3,61 dengan kriteria jawaban baik, hal ini dikarenakan pegawai teliti dan dapat menyelesaikan pekerjaan sesuai dengan batas waktu yang diberikan kepadanya.

Lalu pada indikator efisiensi waktu dalam bekerja berada pada rata-rata 3,22 dengan kriteria jawaban cukup baik dikarenakan pegawai tidak menggunakan waktu dengan baik seperti menunda-nunda suatu pekerjaan. Indikator ketepatan menyelesaikan pekerjaan sesuai dengan waktu yang ditentukan berada pada rata-rata 2,96 dengan kriteria jawaban cukup baik, dikarenakan masih adanya beberapa pegawai yang kurang memanfaatkan waktu bekerjanya sehingga belum mampu mencapai sasaran kerja dengan tepat waktu. Pada indikator pertanggungjawaban dalam menyusun anggaran memperoleh nilai ratarata 3,43 dengan kriteria jawaban baik, hal ini dikarenakan pegawai harus bertanggungjawab atas anggaran yang diberikan dengan menyesuaikan keperluan pegawai. Indikator cara mengunakan anggaran untuk keperluan pekerjaan memperoleh nilai rata-rata 3,52 dengan kriteria jawaban baik, dikarenakan anggaran yang diberikan sesuai dengan yang dibutuhkan pegawai dalam bekerja.

Kemudian pada dimensi perilaku kerja pada indikator tingkat pelayanan kepada masyarakat memperoleh nilai ratarata 3,52 dengan kriteria jawaban baik, hal ini dikarenakan pegawai berusaha memberikan pelayanan yang baik kepada masyarakat. Indikator sikap pegawai saat 
memberikan pelayanan memperoleh nilai rata-rata 3,48 dengan kriteria jawaban baik, dikarenakan sikap pegawai dalam memberikan pelayanan harus sebaik mungkin kepada masyarakat. Pada indikator tingkat kejujuran pegawai dalam bekerja memperoleh nilai rata-rata 3,57 dengan kriteria jawaban baik, hal ini dikarenakan pegawai memiliki tingkat kejujuran yang baik dalam bekerja. Selanjutnya pada indikator tingkat keberanian dalam pengambilan resiko memperoleh nilai ratarata 3,48 dengan kriteria jawaban baik, hal ini dikarenakan pegawai selalu mempertimbangkan dengan baik setiap resiko terkait dengan pekerjaannya.

Indikator semangat pegawai dalam bekerja memperoleh nilai rata-rata 3,48 dengan kriteria jawaban baik, hal ini dikarenakan pegawai saling memotivasi dalam melakukan pekerjaan sehingga mereka semangat untuk bekerja. Kemudian pada indikator pencapaian pegawai dalam, menyelesaikan pekerjaan berada pada ratarata 3,57 dengan kriteria jawaban baik, hal ini dikarenakan adanya target yang harus dicapai oleh para pegawai dalam menyelesaikan pekerjaannya. Indikator tingkat kehadiran pegawai dalam bekerja berada pada rata-rata 3,48 dengan kriteria jawaban baik, hal ini terjadi karena pegawai mulai mendisiplinkan diri untuk selalu hadir di hari kerja yang sudah ditetapkan. Indikator kepatuhan terhadap peraturan memperoleh nilai rata-rata 3,61 dengan kriteria jawaban baik, hal ini dikarenakan pegawai menaati peraturan yang ditetapkan instansi seperti pemakaian seragam dinas.

Lalu indikator kerja sama pegawai atas tugas yang dibebankan berada pada rata-rata 3,43 dengan kriteria jawaban baik, hal ini dikarenakanmasih adanya beberapa pegawai yang lebih mementingkan pekerjaannya dibandingkan bekerjasama dengan pegawai lain dalam menyelesaikan pekerjaan yang dibebankan kepadanya.

Selanjutnya pada indikator pegawai dalam memberikan ide atas tugas yang dibebankan memperoleh nilai rata-rata 3,57 dengan kriteria jawaban baik, hal ini karena pegawai memiliki ide dan kreativitas untuk menyelesaikan beban pekerjaan. Pada indikator kerjasama pegawai dalam bekerja memperoleh nilai rata-rata 3,48 dengan kriteria jawaban baik, hal ini dikarenakan adanya hubungan kerja sama yang baik diantara pegawai dalam melaksanakan pekerjaan. Terakhir pada indikator kemampuan pimpinan dalam bekerja sama dengan rekan kerja berada pada rata-rata 3,48 dengan kriteria jawaban baik, dikarenakan pimpinan memiliki kemampuan dalam menjalin kerja sama yang baik terhadap semua pegawainya.

Dari total jawaban responden mengenai dimensi sasaran kerja pegawai dan perilaku kerja mendapat nilai rata-rata sebesar 3,47 dengan kriteria jawaban baik. Kemudian nilai rata-rata tertinggi 3,61 dengan kriteria jawaban baik untuk dimensi sasaran kerja pegawai pada indikator kualitas hasil kerja pegawai dan ketelitian pegawai dalam bekerja. Sedangkan nilai rata-rata terendah sebesar 2,96 dengan kriteria jawaban cukup baik untuk dimensi sasaran kerja pegawai pada indikator ketepatan dalam menyelesaikan pekerjaan sesuai waktu yang telah ditentukan.

\section{b. Deskriptif Kuantitatif}

\section{1) Analisa Regresi Linear Berganda}

Penelitian ini memiliki Analisis regresi linier berganda digunakan untuk mengetahui pengaruh variabel bebas (X) dan variabel terikat $(Y)$, dimana $X$ adalah rekrutmen, penempatan, dan $\mathrm{Y}$ adalah kinerja pegawai.Berdasarkan dari hasil analisis dengan menggunakan program SPSS 21 maka diperoleh hasil regresi antara Rekrutmen dan Penempatan terhadap Kinerja Pegawai seperti tabel berikut:

Tabel 2

Analisis Regresi Berganda

\begin{tabular}{|c|c|c|c|}
\hline \multirow[t]{2}{*}{ Model } & \multicolumn{2}{|c|}{$\begin{array}{c}\text { Unstandardized } \\
\text { Coefficients }\end{array}$} & \multirow{2}{*}{$\begin{array}{c}\begin{array}{c}\text { Standardized } \\
\text { Coefficients }\end{array} \\
\text { Beta }\end{array}$} \\
\hline & $B$ & $\begin{array}{c}\text { Std. } \\
\text { Error }\end{array}$ & \\
\hline $\begin{array}{l}\text { Kinerja } \\
\text { Pegawai }\end{array}$ & 6,059 & 10,836 & \\
\hline I Rekrutmen & ,558 &, 250 & ,418 \\
\hline Penempatan & 634 & ,266 & (447 \\
\hline
\end{tabular}

a. Dependent Variable: Kinerja Pegawai

Sumber: Hasil pengolahan SPPS 21 (2018)

Berdasarkan hasil pengolahan data pada tabel 2 di atas, diperoleh model persamaan 


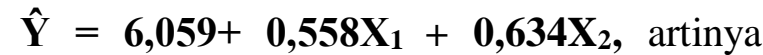
terdapat pengaruh positif antara rekrutmen $\left(\mathrm{X}_{1}\right)$ dan penempatan $\left(\mathrm{X}_{2}\right)$ terhadap kinerja pegawai (Y) pada Kantor Pelayanan Perbendaharaan Negara (KPPN) Pematangsiantar.

\section{2) Analisis Koefisien Korelasi dan} Koefisien Determinasi

Perhitungan korelasi berupa derajat atau kedalaman hubungan fungsional yang menjelaskan hubungan antara perubah, dinyatakan dengan yang dinamakan korelasi yang sering disimbolkan dengan $\mathrm{R}$, nilai $\mathrm{R}$ dapat dihitung menggunakan SPSS versi 21. Hasil korelasi dan koefisien determinasi dapat dilihat pada tabel 3 berikut ini:

Tabel 3

Korelasi dan Determinasi

\begin{tabular}{|l|c|r|r|r|}
\hline Model & $\boldsymbol{R}$ & $\begin{array}{c}\boldsymbol{R} \\
\text { Square }\end{array}$ & $\begin{array}{c}\text { Adjusted } \\
\boldsymbol{R} \\
\text { Square }\end{array}$ & $\begin{array}{r}\text { Std. Error of } \\
\text { the Estimate }\end{array}$ \\
\hline 1 & $\mathbf{7 9 7}^{\mathrm{a}}$ & $\mathbf{6 3 5}$ &, 598 & 6,586 \\
\hline
\end{tabular}

a. Predictors: (Constant), Penempatan (X2), Rekrutmen (X1)

b. Dependent Variable:Kinerja Pegawai (Y) Sumber: Hasil pengolahan SPPS 21 (2018)

Dari hasil korelasi pada tabel 3 di atas diperoleh nilai sebesar 0,797 yang artinya terdapat hubungan yang kuat dan positif.Kemudian diperoleh nilai koefisien determinasi sebesar 0,635, artinya tinggi rendahnya kinerja pegawai (Y) pada Kantor Pelayanan Perbendaharaan Negara (KPPN) Pematangsiantar sebesar $63,5 \%$ dapat dijelaskan oleh rekrutmen $\left(\mathrm{X}_{1}\right)$ dan penempatan $\left(\mathrm{X}_{2}\right)$ sedangkan sisanya sebesar $36,5 \%$ dipengaruhi oleh faktor lain.

\section{3) Uji Hipotesis}

\section{a) Uji Simultan (Uji F)}

Uji F digunakan untuk mengetahui apakah variabel bebas (rekrutmen dan penempatan) berpengaruh terhadap variabel terikat (kinerja pegawai) secara bersamasama atau simultan. Pengujian ini dapat dilihat dari tabel berikut:
Tabel 4

Perkiraan Nilai Fhitung

\begin{tabular}{|l|r|r|r|r|r|}
\hline Model & $\begin{array}{c}\text { Sum of } \\
\text { Squares }\end{array}$ & $\begin{array}{c}\text { D } \\
\boldsymbol{f}\end{array}$ & $\begin{array}{c}\text { Mean } \\
\text { Square }\end{array}$ & $\boldsymbol{F}$ & Sig. \\
\hline Regressio & 1508,08 & 2 & 754,04 & $\mathbf{1 7 , 3 8}$ & $\mathbf{0 0 0}$ \\
$n$ & 4 & & 2 & $\mathbf{3}$ & $\mathbf{b}$ \\
1 Residual & 867,568 & 2 & 43,378 & & \\
& & 0 & & & \\
Total & 2375,65 & 2 & & & \\
4 & 2 & & & \\
\hline
\end{tabular}

a. Dependent Variable: Kinerja Pegawai (Y) b. Predictors: (Constant), Penempatan (X2), Rekrutmen (X1)

Sumber: Hasil pengolahan SPPS 21 (2018)

Berdasarkan tabel 4 diatas diperoleh nilai $F_{\text {hitung }}$ sebesar $17,383>F_{\text {tabel }}$ dengan $(0,05 ; 2$ vs 20$)$ sebesar 3,49 , atau dengan signifikan $0,000 \leq \alpha 0,05$, maka $\mathrm{H}_{0}$ ditolak, artinya rekrutmen dan penempatan berpengaruh positif dan signifikan terhadap kinerja pegawai pada Kantor Pelayanan Perbendaharaan Negara (KPPN) Pematangsiantar.

\section{b) Uji Parsial (Uji t)}

Pengujian hipotesis dilakukan untuk mengetahui apakah variabel rekrutmen dan penempatan yang di uji berpengaruh terhadap kinerja pegawai. Jika $t_{\text {hitung }}>t_{\text {tabel }}$ atau signifikansi $\leq 0,05$ maka $\mathrm{H}_{0}$ ditolak. Untuk menguji kebenarannya maka dilakukan pengujian hipotesis dengan menggunakan program aplikasi SPSS versi 21.

Tabel 5

Perkiraan Nilai thitung

\begin{tabular}{|c|c|c|c|}
\hline & Model & $t$ & Sig. \\
\hline \multirow{3}{*}{1} & (Constant) & .559 & .582 \\
\hline & Rekrutmen & 2.227 & .038 \\
\hline & Penempatan & 2.383 & .027 \\
\hline
\end{tabular}

a. Dependent Variable: KinerjaPegawai Sumber: Hasil pengolahan SPPS 21 (2018)

Berdasarkan tabel 5 di atas, diperoleh nilai $t_{\text {hitung }}$ pada $X_{1}$ (rekrutmen) sebesar $2,227>\mathrm{t}_{\text {tabel }}$ dengan $\mathrm{df}=\mathrm{n}-\mathrm{k}-1 \quad(23-2-1=20)$ sebesar 2,085 atau taraf signifikan $0,038 \leq \alpha$ 0,05 , maka $\mathrm{H}_{0}$ ditolak, artinya rekrutmen berpengaruh positif dan signifikan terhadap kinerja pegawaipada Kantor Pelayanan Perbendaharaan Negara (KPPN) Pematangsiantar.

Nilai $t_{\text {hitung }}$ pada $\mathrm{X}_{2}$ (penempatan) sebesar 2,383 $>t_{\text {tabel }}$ dengan $\mathrm{df}=\mathrm{n}-\mathrm{k}-1$, (23- 
2-1=20) sebesar 2,085 atau taraf signifikan $0,027 \leq \alpha 0,05$, maka $\mathrm{H}_{0}$ ditolak, artinya penempatan berpengaruh positif dan signifikan terhadap kinerja pegawai pada Kantor Pelayanan Perbendaharaan Negara (KPPN) Pematangsiantar.

\section{Evaluasi}

\section{a. RekrutmenPada Kantor Pelayanan Perbendaharaan Negara (KPPN) Pematangsiantar}

Pada dimensi kompetitif dengan indikator kemampuan diperoleh dengan nilai rata-rata 3,48 dengan kriteria jawaban baik, cara meningkatkan kemampuan ialah dengan memberikan pelatihan kepada pegawai agar timbul kemampuan bersaing mereka dalam menyelesaikan pekerjaan. Selain itu dimensi transparan, pada indikator keterbukaan pemerintah di tempat kerja diperoleh nilai rata-rata 3,52 dengan kriteria jawaban baik, cara meningkatkannya ialah dengan memberikan pengumuman kepada pegawai melalui media penyebaran informasi seperti internet yang mudah diakses oleh setiap pegawai. Indikator kebebasan yang dimiliki setiap orang selama bekerja diperoleh nilai ratarata 3,48 dengan kriteria jawaban baik, cara meningkatkannya dengan lebih memberi kebebasan kepada pegawai agar pegawai merasa bahwa ia dapat dipercaya dalam melakukan sebuah pekerjaan.

Terakhir dimensi bersih dari praktik korupsi pada indikator pengendalian yang diberikan oleh pihak instansi diperoleh dengan nilai rata-rata 3,48, cara meningkatkannya dengan mengadakan pemeriksaan rutin setiap pencapaian yang diperoleh oleh setiap pegawai.

\section{b. Penempatan Pada Kantor Pelayanan \\ Perbendaharaan Negara (KPPN) \\ Pematangsiantar}

Pada dimensi faktor pendidikan dengan indikator penyesuaian pendidikan dengan beban kerja memperoleh nilai ratarata 3,43 dengan kriteria jawaban baik, cara meningkatkannya ialah dengan memberikan pelatihan kepada pegawai dengan latar belakang pendidikan pegawai serta membantu pegawai yang mengalami kesulitan agar pekerjaan tersebut menjadi optimal. Pada dimensi faktor kesehatan fisik dan mental dengan indikator kondisi fisik selama bekerja diperoleh dengan niali ratarata 3,43 kriteria jawaban baik, cara meningkatkannya dengan mengadakan olahraga bersama guna meningkatkan kondisi fisik yang sehat dan dapat meningkatkan kinerja pegawai.

Pada dimensi kompetensi dengan indikator tingkat pengetahuan dengan nilai rata-rata 2,91 dengan kriteria jawaban cukup baik, untuk mengatasi hal ini sebaiknya pegawai yang kurang mengerti teknologi diikutsertakan dalam pelatihan khusus agar pekerjaan yang menyangkut teknologi tersebut dapat terselesaikan dengan baik. Dalam hal ini dapat dilihat bahwa penempatan pada Kantor Pelayanan Perbendaharaan Negara (KPPN) Pematangsiantar sudah dikategorikan baik. Walaupun demikian, diharapkan kepada setiap pihak, baik pegawai maupun pimpinan instansi untuk menjalin kerja sama dalam menyelesaikan tugas-tugas dan dapat mengikuti pelatihan yang diadakan oleh instansi.

\section{c. Kinerja Pegawai Pada Kantor Pelayanan Perbendaharaan Negara (KPPN) Pematangsiantar}

Pada dimensi sasaran kerja pegawai pada indikator efisiensi waktu dalam bekerja diperoleh nilai rata-rata 3,22 dengan kriteria jawaban cukup baik, cara mengatasinya pegawai harus lebih memanfaatkan waktu dan tidak menunda setiap pekerjaan yang telah diberikan agar pekerjaan tersebut terselesaikan dengan baik. Pada indikator ketepatan dalam menyelesaikan pekerjaan sesuai waktu diperoleh nilai rata-rata 2,96 dengan kriteria jawaban cukup baik, cara mengatasinya ialah saat pegawai mengerjakan pekerjaan harus lebih memperhatikan waktu agar pekerjaan dapat selesai sesuai dengan waktu yang ditentukan. Terakhir indikator pertanggungjawaban dalam menyusun anggaran untuk keperluan pekerjaan diperoleh nilai rata-rata 3,43 dengan kriteria jawaban baik, untuk meningkatkannya sebaiknya pegawai membuat daftar keperluan pegawai agar tidak terjadinya kesalahpahaman dalam penggunaan anggaran. 
Pada dimensi perilaku kerja, dengan indikator kerjasama pegawai atas tugas yang dibebankan memperoleh nilai rata-rata 3,43 dengan kriteria jawaban baik, cara meningkatkannya ialah dengan memberi dukungan kepada pegawai yang kesulitan kerja dan selalu menjalin kerja sama dalam menyelesaikan tugas yang dibebankan serta menciptakan keharmonisan tiap pegawai dalam bekerja sama.

Dalam hal ini dapat dilihat bahwa kinerja pegawai pada Kantor Pelayanan Perbendaharaan Negara (KPPN) Pematangsiantar sudah dikategorikan baik.Untuk itu, sebaiknya pegawai lebih memaksimalkan tanggung jawab, kemampuan dan jujur dalam mengerjakan dan menyelesaikan pekerjaan yang diberikan oleh pihak instansi.

\section{KESIMPULAN DAN SARAN}

\section{Kesimpulan}

a. Hasil analisis deskriptif kualitatif tentang rekrutmen diperoleh rata-rata jawaban keseluruhan 3,63 dengan kriteria jawaban baik. Kemudian nilai rata-rata tertinggi 3,74 dengan kriteria jawaban baik untuk dimensi adil pada indikator kesetaraan antar pegawai di tempat kerja dan dimensi objektif pada indikator proses rekrutmen yang dilakukan instansi dan penentuan kelulusan yang digunakan instansi. Sedangkan nilai rata-rata terendah sebesar 3,48 dengan kriteria jawaban baik untuk dimensi kompetitif pada indikator kemampuan anda di tempat kerja, dimensi transparan pada indikator tingkat kebebasan yang dimiliki setiap orang selama bekerja, dan dimensi bersih dari praktik korupsi pada indikator pengendalian yang diberikan oleh pihak instansi.

b. Hasil analisis deskriptif kualitatif tentang penempatan diperoleh rata-rata jawaban keseluruhan 3,47 dengan kriteria jawaban baik. Kemudian nilai rata-rata tertinggi 3,65 dengan kriteria jawaban baik untuk dimensi faktor usia pada indikator penyesuaian usia dengan pekerjaan dan dimensi kompetensi pada indikator tingkat keterampilan. Sedangkan nilai rata-rata terendah sebesar 2,91 dengan kriteria jawaban cukup baik untuk dimensi faktor kompetensi pada indikator tingkat pengetahuan.

c. Hasil analisis deskriptif kuantitatif tentang kinerja pegawai diperoleh nilai rata-rata jawaban keseluruhan 3,47 dengan kriteria jawaban baik. Kemudian nilai rata-rata tertinggi 3,61 dengan kriteria jawaban baik untuk dimensi sasaran kerja pegawai pada indikator kualitas hasil kerja pegawai dan ketelitian pegawai dalam bekerja. Sedangkan nilai rata-rata terendah sebesar 2,96 dengan kriteria jawaban cukup baik untuk dimensi sasaran kerja pegawai pada indikator ketepatan dalam menyelesaikan pekerjaan sesuai waktu yang telah ditentukan.

d. Berdasarkan dari hasil analisis regresi linier berganda diperoleh jawaban yaitu adanya pengaruh positif antara rekrutmen $\left(\mathrm{X}_{1}\right)$ dan penempatan $\left(\mathrm{X}_{2}\right)$ terhadap kinerja pegawai (Y) pada Kantor Pelayanan Perbendaharaan Negara (KPPN) Pematangsiantar.

e. Dari hasil analisis korelasi diperoleh jawaban yaitu terdapat hubungan yang kuat dan positif antara rekrutmen, penempatan, dengan kinerja pegawai pada Kantor Pelayanan Perbendaharaan Negara (KPPN) Pematangsiantar. Kemudian juga diperoleh faktor lain yang menyebabkan baik tidaknya kinerja pegawai (Y) pada Kantor Pelayanan Perbendaharaan Negara (KPPN) Pematangsiantar dapat dijelaskan oleh rekrutmen $\left(\mathrm{X}_{1}\right)$ dan penempatan $\left(\mathrm{X}_{2}\right)$ sedangkan sisanya dipengaruhi oleh faktor lain seperti seleksi, pelatihan, pengembangan karir, kompensasi, kepuasan kerja, penilaian kerja dan variabel lain yang tidak diteliti dalam penelitian ini.

f. Hasil pengujian hipotesis secara simultan dengan uji $\mathrm{F}_{0}$ ditolak, artinya terdapat pengaruh yang positif dan signifikan antara variabel rekrutmen dan penempatan terhadap kinerja pegawai pada Kantor Pelayanan Perbendaharaan negara (KPPN) Pematangsiantar.

g. Hasil pengujian hipotesis secara parsial untuk variabel $\mathrm{X}_{1}$ (rekrutmen) dengan uji 
t $\mathrm{H}_{0}$ ditolak, artinya terdapat pengaruh yang positif dan signifikan antara variabel rekrutmen dan penempatan terhadap kinerja pegawai pada Kantor Pelayanan Perbendaharaan Negara (KPPN) Pematangsiantar. Kemudian pengujian hipotesis secara parsial untuk variabel $\mathrm{X}_{2} \quad$ (penempatan) dengan perolehan uji $\mathrm{t}$ maka $\mathrm{H}_{0}$ ditolak, artinya penempatan berpengaruh positif dan signifikan terhadap kinerja pegawai pada Kantor Pelayanan Perbendaharaan Negara (KPPN) Pematangsiantar.

\section{E. DAFTAR PUSTAKA}

Bangun, W. 2012. Manajemen Sumber Daya Manusia. Jakarta: Penerbit Erlangga.

Daft, Richard L. 2002. Manajemen, Jilid 1, edisi kelima.Jakarta: Erlangga.

Fahmi, I. 2016. Manajemen Sumber Daya Manusia, Teori dan Aplikasi. Bandung: Penerbit Alfabeta.

Gomes, Faustino Cardoso. 2003. Manajemen Sumber Daya Manusia. edisi kedua. Yogyakarta: Andi.

Handoko, T. Hani. 2003. Manajemen. Yogyakarta: BPFE.

Mangkunegara, A. P. 2005. Evaluasi Kinerja. Bandung: Penerbit Refika Aditama.

Mathis. Robert L \& John H. Jackson 2006. Human Resource Manajement, edisi kesepuluh. Jakarta: Penerbit Salemba Empat.

Mondy, R. W. 2008. Manajemen Sumber Daya Manusia, Jilid 1, Edisi Kesepuluh.Jakarta: Penerbit Erlangga.

Nurjaman, K. 2014. Manajemen Personalia. Bandung: Penerbit Pustaka Setia

Peraturan IndonesiaNomor $46 \quad$ Tahun 2011.Tentang Penilaian Prestasi Kerja Pegawai Negeri Sipil .

Rivai, Veithzal. 2004. Manajemen Sumber Daya Manusia untuk Perusahaan. Jakarta: Penerbit Raja Grafindo Persada.

Robbins, Stephen P dan Mary. Coulter. 2010. Manajemen.Jilid 1, Edisi Kesepuluh.Jakarta: Penerbit Erlangga.
Suwatno. 2003. Azas-Azas Manajemen Sumber Daya Manusia. Bandung: Penerbit Suci Press.

Zainal Veithzal Rivai, dkk. 2015. Manajemen Sumber Daya Manusia Untuk Perusahaan. Jakarta: Rajawali Pers. 